(C) 2017. This manuscript version is made available under the CC-BY-NC-ND 4.0 license http:/creativecommons.org/licenses/by-nc-nd/4.0/

Lanas, Maija (2017) Giving up the lottery ticket: Finnish beginning teacher turnover as a question of discursive boundaries. Teaching and Teacher Education. 68. 68-76.

https://doi.org/10.1016/i.tate.2017.08.011

Giving up the lottery ticket: Finnish beginning teacher turnover as a question of discursive boundaries

\begin{abstract}
Teachers leaving the profession is an increasing trend also in Finland, which is interesting because many of the explanations found in other international contexts do not apply. The Finnish context, in which teachers are not controlled officially in any way, offers a unique context for investigating implicit control mechanisms and their relationship to teacher turnover. The research shows how intersecting discourses work in ways that may lead to self-exclusion of beginning teachers who cannot find a subject position within school. This happens unofficially and implicitly in a context that explicitly emphasizes teacher freedom, autonomy and societal appreciation. Teacher turnover provides tool for making visible the discursive boundaries that might otherwise stay hidden.
\end{abstract}

KEYWORDS: poststructuralism, subjectification, teacher turnover, teacher attrition, transition to work, Finland 


\section{Giving up the lottery ticket: Finnish beginning teacher turnover as a question of discursive boundaries}

\section{Introduction}

Internationally, teachers leaving the profession poses a significant challenge. In European countries, approximately $30-40 \%$ of new teachers select a field other than teaching (Wang, Hall, \& Rahimi, 2015 , p. 121), and $30-50 \%$ of new teachers change their profession during the first five years because of work-related exhaustion (Bruinsma \& Jansen, 2010; Cochran-Smith, 2004; Johnson \& Birkeland, 2003; Rots, Kelchtermans, \& Aelterman, 2012; Skaalvik \& Skaalvik, 2011; Struyven \& Vanthournout, 2014; Thomson, Turner, \& Nietfiel, 2012; Wang, Hall \& Rahimi, 2015). Existing research indicates that teachers leave the profession because of external factors such as heavy workloads, low salaries, challenging students, and the low social status of the profession (Kyriacou \& Kunc, 2007; Webb et al., 2004), and because of the increasing pressures created by accountability measures (e.g., Clandinin, Downey, \& Huber, 2009).

In order to make more sense of teacher turnover, Clandinin (2000) has suggested that we should pay attention to new teachers' experiences of professional practice. As documented in multiple studies, the transition from "student of teaching" to "teacher of students" (Smith \& Ingersoll, 2004, p. 683) is a challenging one. For example, Moir (1999) described how teachers in their first year go through a series of phases, from eager anticipation to shock at the reality of their situation to a survival period that ends in disillusionment, self-doubt, and reflection. Harfitt (2015), in turn, concluded that contextual factors, especially support mechanisms, are key to understanding why beginning teachers leave the profession. Schaefer (2013, p. 269), on the other hand, discussed beginning teacher attrition as a challenge of identity making and identity shifting. According to Schaefer, beginning teachers enter teaching with preconceived ideas of who they might be as a teacher. These preconceptions include how they expect to live out staff relationships, relationships with students, relationships with subject matter, and relationships with parents, all of which are challenged as they enter the profession (Schaefer, 2013, p. 269). Similarly, Rots, Kelchtermans and Aelterman (2012, pp. 4-5, 8) found that the emotional labor required to deal with the normative, emotional, and social aspects of teaching proved far more intrusive and pervasive for student teachers than the technical aspects of the job. Pillen, Beijaard, and den Brok (2013) looked at these issues in terms of professional 'identity tensions' under three themes: 1 ) the change in role from student to teacher; 2) conflicts between desired and actual support given to students; and 3) conflicting conceptions of learning to teach. They note that professional identity tensions are not necessarily a negative factor in professional development but also appear to be a positive "tool" for teacher learning (Pillen, Beijaard \& den Brok, 2013, p. 674). Finally, Clandinin, Downey and Huber (2009) suggested that the changing landscape-for instance, the emergence of standardized 
achievement testing and accountability-contributes to teachers leaving the profession. They argued that the increasing international focus on the use of test scores as a means of measuring achievement engenders a central tension between what each teacher has come to know about the student and how the institutional machinery knows the student. They argue that this tension may be unbearable for teachers whose original motivation to enter the profession comes to be challenged by the institution's perspective of children.

Teacher attrition in the Finnish context brings an interesting twist to this discussion. In Finland, exact figures do not exist, but an estimated $10-20 \%$ of graduating teachers choose professional fields other than teaching (see e.g. Nissinen \& Välijärvi, 2011; Malinen, Väisänen, \& Savolainen, 2012; Webb et al., 2004). Although this is a reasonably small number, the experiences of these $10-20 \%$ may tell us something about teaching in Finland. Leaving teaching is an increasing trend in Finland (Ostinelli, 2009), which is interesting because many of the explanations found in other international contexts do not apply. Although Finnish teachers' salaries are not high compared with many other professions nationally, the social status of teachers is unusually high, both domestically and internationally (OECD, 2014; Malinen, Väisänen \& Savolainen, 2012; Nissinen \& Välijärvi, 2011; Simola, 2007). Domestically, skilled Finnish teachers are valued as a factor in Finland's success after the Second World War and have earned international praise since the publication of the first OECD PISA results at the beginning of the millennium. Moreover, Finnish teachers have not been subjected to the increasingly popular high-stakes testing or accountability measures used in many other countries. In fact, there are no official control mechanisms for Finnish teachers: no school inspectorate, no standardized testing, no detailed national curriculum, and no officially required teaching materials. The education system has been decentralized since the 1970s, and teachers are expected to make most of the decisions as experts in their local context.

To become a qualified class teacher, the prerequisite is a university-based master's degree (usually in education). Finnish student teachers are, in general, highly motivated to become teachers. The demanding selection process tests this motivation, as fewer than $10 \%$ of applicants are accepted into teacher training. For example, in 2014 at the University of Oulu, where the present research was conducted, there were 1866 applicants for the teacher education programs, of whom only 80 were accepted (fixed yearly intake). The application procedure includes two stages: a multiplechoice exam, followed by an interview and demonstration of a skill. Some applicants have worked for years to gain the necessary experience to convince the board of their suitability; many have spent a year completing university-level studies in education to gain a head start in the exam while others have worked as teachers' assistants to gain practical experience and to convince the board of their motivation.

On being accepted into the program, it takes five years to qualify. Upon entering the program, students commonly describe the feeling as the equivalent of having the winning lottery ticket. That being so, it is surprising and interesting that between 10 and $20 \%$ abandon their career choice and leave the profession following graduation. What happens in that transition from studying to working? Why do they give up the lottery ticket just as they are about to cash it in? Answering these 
questions will provide more insights into the challenges and choices made by leaving teachers everywhere, and into the reasons behind those choices.

This study mainly follows the lead of both Clandinin (2009) and Schaefer (2013) in looking at beginning teacher attrition as a question of identity making in the changing landscape of teaching. However, I have applied a different set of concepts; drawing on the work of feminist poststructuralists I speak of subjectification rather than identity making and shifting. This paper thus locates within the so-called "discursive turn", exploring those processes of constitution by which phenomena come to be what they are taken to be. The purpose of the study is to shed light on the discourses within which individual beginning class teachers choose to leave, and the methodology draws on poststructuralist thinking. Teacher turnover is used as tool for making visible the discursive boundaries that might otherwise stay hidden.

\section{A poststructuralist take on the beginning teacher's self}

In poststructuralism, self is seen as a dynamic, never-ending process: always a practice of "becoming," always taking place in relation to something (see also Holquist, 1990). Self, then, is both a verb and a relation, the subject of a continuous process of being constituted, reconstituted, and reconstituting (see Taguchi, 2005). The poststructural perspective of self as a verb and a relation differs from humanist discourses, within which self or existence is located "inside" the individual. According to Youdell (2006), in humanist discourses, people are who they are because they choose to be so, or because of their inheritance (or some combination of both). From the poststructural perspective, however, self is not pre-existing, self-knowing, and continuous; rather, an individual becomes a subject through their ongoing constitution in and by discourse (Youdell, 2006, p. 35). As Taguchi (2005) explains,

The stories we tell can be understood as the result of what kind of meaning making is available to the subject; that is, what the discursive conditions are in terms of available discourses (meanings), and how the context is discursively constituted. This happens not only in relation to other subjects, but also in relation to situated discursive meanings in terms of geography, the institution, time, architecture, items, and aesthetics. (Taguchi, 2005, p. 250).

This means that "student teacher" or "teacher" is not something that some individuals simply are (or are not) but something that they do. However, they are not free to do it as they wish but must do it within discursive boundaries that work to define multiple categories, such as women, men, disabled, ethnic, European, adult, gifted, and special student. In other words, although each beginning teacher constructs their own idea of "teacher," this is not an empty category for student teachers to fill as they wish while learning about their future work. The idea of "teacher" is already loaded with multiple contexts, people, and competing forms of knowledge, desires, and fears. The discourses therefore prescribe not only what is desirable but also what is recognizable as an 
acceptable form of subjectivity (Davies et al., 2001, p. 172). This comes close to Coldron and Smith's account: "Being a teacher is a matter of being seen as a teacher by himself or herself and by others; it is a matter of acquiring and then redefining an identity that is socially legitimated" $(1999$, p. 712).

In each socio-cultural-historical context, slightly different things are expected in terms of habitus, speech, emotions, and conduct from those who wish to be taken seriously as teachers in that context. Becoming a teacher entails learning to read the surroundings for implicit rules regarding what a teacher can be, and (drawing on Butler, 1990, 1993) learning to perform the position of a teacher (see also Davies et al., 2001, p. 181; Lanas \& Kelchtermans, 2015). Performing the position is not simply about acquiring the appropriate outfit and manners; it involves identifying what can and cannot be said, felt, or thought by someone in a particular subject position. In this way, one becomes a subject within a discourse by demonstrating subjectivity within discourses. It is not a matter of learning to "fake" behavior but is instead deeply personal, emotional, and part of the self.

The theoretical stance adopted here acknowledges that no part of us is unpenetrated by societal discourses, and that our very selves are constituted and reconstituted through negotiation of discursive boundaries. Individuals do make choices, but any such choice stems not so much from the individual but from the conditions of possibility. However, discourses are not imposed on people from above, nor do they act upon us as external forces. Rather, they circulate in the everyday, acted out by us. We act out discourses as we make ourselves subjects-teacher, woman, man, European, American-and as we perform subjectivity within specific discourses, we produce some version of those discourses in the world.

Youdell (2006, p. 36) suggested that discursive performatives are deployed by: 1) spoken and written language (e.g., direct naming of social and biographical categories such as woman, special student, teacher, or supposed characteristics like clever or pleasant; 2) representations (e.g., powerful cultural-historical images of what teachers are like/should be like); 3) habitus (e.g., bodily gestures, adornments, acts, how we carry ourselves, how we wear clothes, how we engage with each other); and 4) silence (what is not spoken, done, said, or expressed). In order to work, performatives must "make sense"; they must be recognizable in the discourses that frame their deployment. This means that the performatives taken on by aspiring teachers must "cite" (Youdell, 2006) the rules of the surrounding discourses if they are to remain intelligible within those discourses as aspiring teachers. At the same time, it is precisely the citing of performatives that keeps the performatives alive.

In this way, when becoming subjects in specific educational and institutional discourses, beginning teachers cite the enduring educational and institutional discourses that determine who students or teachers are and what schools are about. In so doing, they also contribute to producing these discourses. Student teachers who fail to cite the appropriate discourses, or who take on performatives that are counter to prevailing institutional discourses, may be constituted outside the bounds of acceptability as a teacher (Phelan et al., 2006; Sumara, Davis, \& Iftody, 2008; Youdell, 2006). In the process, some individuals come to be constituted by intersecting discourses as inside educational institutions, and others come to be constituted as outside of these (Youdell, 2006). Furthermore, not all subjects can deploy all performatives equally within a particular discourse. 
Depending on how discourses intersect-for example, in respect of gender or ethnicity-some subjectivities and positions are rendered available while others remain unavailable. Depending on their conditions of possibility, while some individuals may undergo a transformation in order to "change into" a teacher, adapting their mind, body, and emotions, others may see their education as actualizing an already identified potential within them (Malderez, Hobson, Tracey, \& Kerr, 2007, p. 230). Some may not feel they can adapt at all, and so abandon their aspiration to be teachers (Rots et al., 2012).

It is suggested here that the teacher-self is constituted performatively. In other words, a "teacher" does not subsist in policy documents, teacher education ideals, official guidelines, or media representations but rather in how everyday practitioners read these, and the discursive spaces in which they negotiate these in their everyday practice. In the Finnish context, teachers are extremely motivated on entering training, having worked hard to be accepted. They are officially free to realize their identities as they wish; they have explicit policy-level support for realizing their wildest pedagogical fantasies; and there is no official pressure to achieve measurable results. For these reasons, it is a particularly fruitful context in which to study how beginning teachers negotiate implicit discourses. Where anything is officially possible and even encouraged, how is it possible that some beginning teachers cannot find an available subject position or create one for themselves?

\section{The research process}

Davies et al. (2001, p. 181) argued that when the individual "takes on," or subscribes to, any subject position, she typically believes herself to be the author of the discourse she is performing. It follows that those who easily fit into the subject position may not notice the discursive boundaries, which are like invisible walls that are recognizable only when one runs into them. The focus of this research, then, is those beginning teachers who have trouble positioning themselves as authors of Finnish educational discourses. I wanted to hear from graduating students and beginning class teachers ${ }^{1}$ who were thinking about giving up their aspiration to become teachers. The purpose was not to produce generalizable data and results about all novice teachers but to gain in-depth insights into what happens during the transition period, as individuals negotiate with the field of practice they encounter, constituting themselves as authors in that field while simultaneously adapting to it and challenging it. Hoping to learn about the implicit discursive boundaries they may have encountered in the process, I adopted a longitudinal, in-depth approach to purposefully allow beginning teachers to think and rephrase their thoughts and emotions in a dialogue with the researcher.

\footnotetext{
${ }^{1}$ In the Finnish context, these two phases often overlap. Students begin substituting before they graduate, and they often graduate while already working in the field.
} 
Post-structural analysis is sometimes described as a process of "thinking with" theory or data (e.g., Jackson \& Mazzei, 2012). Many poststructuralists and posthumanists shy away from concepts such as "data," "analyzing data," and "coding," arguing that such concepts embody a positivist approach to science (see for example St. Pierre, 2013). The "data" in this research can be seen as a process rather than as a static entity. Data production was interwoven with the analysis and consisted of eleven essays, eight interviews based on the essays, and follow-up e-mail exchanges based on the interviews.

\subsection{Essays}

I began the process by sending the following invitation to students via e-mail:

Are you wondering if you will become a teacher after all? Or maybe you have just confirmed your career choice? I invite you to talk about your experiences. I am particularly interested in what kind of teacher you feel your study environment (formal teacher education, friends, national media) has encouraged you to become, and how you feel about it. (Translated by the author)

The e-mail included information about anonymity, the researcher, and the funder, as well as a link to a website with further details of the project. As I am familiar to many of the students as a lecturer, it is likely that the respondents did not think they were replying to an anonymous researcher. Of the eleven essays I received, ten were written by women and one by a man, all of whom were graduating within the year. Most of the essays were between two and three pages long (single space, font 12). Without exception, the respondents doubted their choice of career, and the essays began with some variant of the statement "Your invitation hit a nerve, I've been thinking about this a lot lately." As I read the essays I realized I had expected to receive essays written by students who "stand out", and then analyse how their subjectivity becomes constituted around what they stand out for. Instead, I read essays from many highly motivated and often high achieving students who had to me always seemed like perfect examples of happy, easygoing, stereotypical teachers. I sent the students a thank-you note with an explanation that I might contact them to arrange an interview within the year.

To begin, I looked for responses to the question "What do graduating students write about doubting their career choice?" I found five general themes explicitly mentioned or directly implied in the essays: "the workload", "the pressure" "the hectic field", "own dissatisfaction", and "own unsuitability." In addition, many of the essays mentioned some kind of "teacher mold." However, despite their immediate visibility, the discussion in the essays around each theme was thin or even lacking. For example, although there was frequent mention of pressure and workload, there were no specific descriptions of what that workload entailed, and pressure was often explained in terms of their own lack of ability to handle pressure. For that reason, the themes that were initially easy to extract from the essays turned out to be fairly empty categories, in that they had no accompanying content. Nor could concrete support for the themes be found beyond the data; beginning teachers know that their suitability has already been assessed before they enter teacher education, and they have thought a lot about their suitability before beginning the difficult process 
of applying for teacher education (Lanas \& Kelchtermans, 2015). They have also been acquainted with the field in five separate internships during their training. In general, Finnish teachers spend fewer weekly hours teaching, planning and correcting than the OECD average ( 28.5 hours versus 30.5 hours) (OECD, 2013) and are not officially placed under external pressure. Instead, they are officially granted autonomy to satisfy all their professional ambitions for life in schools and to craft their teaching as they wish. It is not my intention here to question the reality of the participants' experiences related to attrition; on the contrary, the research addresses how such experiences come to be discursively produced.

\section{First replies - accessible justifications for attrition}

The easily identifiable but empty themes above are of interest not for their explanatory value but for the insights they provide into the discourses within which teachers become subjects as teachers. They tell us that "workload," "pressure," "own suitability," "dissatisfaction," "hectic field," and "pressure" are the available, accessible and acceptable justifications for attrition: ${ }^{2}$ these themes reflect the language available to the respondents as speakers within the surrounding discourses as they contemplate leaving the profession. In this way, the easily identifiable themes only "take[s] us back to what is known, not only to the experience of our participants but also to our own experience as well" (Jackson \& Mazzei, 2012, p. 12). Postructuralist research, on the other hand, is often seen as a quest for new ways of reading and writing the social and of disrupting the normative and takenfor-granted, seeking ethically welcoming readings and ways of understanding and doing that have been excluded or become invisible or impossible to even think in the shadow of normative truthclaims (Taguchi 2007, 285). The goal for the next stage, then, was to find a way of reaching beyond the easily available language to identify reasons for attrition that may not be describable in that language.

\subsection{Interviews}

Interviews based on the essays were conducted about one year after the respondents wrote them. The purpose of leaving a year between generation of the two sets of data was to allow the beginning teachers' stories to develop over time. In this way, the essays were immediate narratives produced in response to a question that "hit a nerve" while the interviews, in turn, allowed the participants to look back and think with the researcher about their own narratives, with the perspective afforded by temporal distance.

To arrange the interviews, I sent an e-mail invitation to the eleven respondents, one at a time. Eight still had the same e-mail address, responded again, and agreed to come to an interview. All were women; five had graduated during the past year and were now substituting and/or pursuing an alternative career path around Finland; one had already spent over a year working as a teacher without finishing her degree; and two were in the process of graduating. The man responded to

\footnotetext{
${ }^{2}$ It is also notable that social status, salaries or challenging students do not emerge as themes. Within the available language, these are not available (appropriate) responses, even though a teacher's salary in Finland, given the level of training and the cost of living, is average at best (average initial wage 28854 versus Finland average 30 587) (OECD 2013).
} 
explain that, although he had graduated, he had not been successful in the work field and would therefore prefer that I interview him when he had found a job, so I decided not to press the issue. To direct the interviews toward beginning teacher subjectification and possible discursive boundaries, I sent the following orienting instructions to each respondent before the interview:

[From] the essays, there are two issues I would like to understand better. 1) Many
essays mentioned some kind of teacher mold to which students may feel they are
fitted during teacher education. Do you recognize such a mold? How does it form
you, or does it? 2) Many essays discussed things the teacher should not
say/feel/speak/think. I am trying to understand these better. Can you think of
something that is difficult to think/feel etc. in the role of a teacher? (Translated by
the author)

The interviews lasted about one hour, and centered on one main question: "Why did/do you doubt whether you want to become a teacher?" The essays or interviews triggered additional probing questions, such as "What do you mean by this?" and "Could you tell me more about that?" For example, respondents referred in the interviews to the same general themes identified in the essays, and each time, I asked them to elaborate: "What do you mean by pressure?" "Can you tell me more about the work load?" and so on. During the interviews, all participants deviated from the orienting instructions quite much. I interpreted this as a sign that my questions did not grasp what was central to them, and they directed the discussion to what was central to them as they were thinking about their decision to stay or leave.

\section{Second replies - mutually constructed knowledge of implicit challenges}

I recorded and recapped each interview before sending the revised version to the interviewee for any corrections, comments, additions, or further thoughts. These were for the most part transcripts of the interviews, paraphrased to make expressions shorter, omitting some parts if they did not contribute to the topic but instead focused momentarily, for example, discussing a specific university course unrelated to the issue at hand. All the interviewees sent a reply, and three added insights or corrected the paraphrasing. The entire data construction process, from essay to final email exchange, took one-and-a-half years. During this time, all but one of the respondents had graduated and was involved in substitute teaching. The one who had yet to graduate was engaged in a two-year substituting role.

As it has been presented above, when the respondents discussed why they thought about leaving, they initially used the available language to justify their experiences, and the available language, in turn, emerges within the surrounding discourses, reflecting them, constructing experiences.

In order to reach beyond the available language I read the elaborations focusing on what becomes said when respondents were forced to develop a language beyond the discursively available responses. Two issues emerged:

1) professional silences; and

2) cultural-historical norms for teachers. 
Lanas (2017) Giving up the lottery ticket

Below, I will describe these as they emerged in the research process.

\section{Results}

\subsection{Professional silences}

Mari was a novice teacher who had chosen to stay in the profession, "at least for now", and whose contract has since been extended for two years. Kaarina, in contrast, had decided not to become a teacher. Elaborating on the themes of workload, hectic field and dissatisfaction, Kaarina and Mari described a lack of professional support:

In real-life teaching, you have to make it on your own. You can't ask for help, you can't burden others. When I asked the special educator for help in figuring out what to do with a student, her comment was 'ok then, if you just can't manage' [...] Once, I asked this woman teacher what I should do [about a variety of issues], and she laughed 'whatever you do, never ask anyone. ${ }^{3}$ (Mari' recap)

No one there has time to talk about things, there is no space to disagree or even think together. The values behind the actions are not discussed. People talk about how problematic something is, but not about what they could do about it. There's no one willing to reflect with you. It's basically either accept things as they are or keep out. I choose to keep out. (Kaarina, interview, elaborating on 'unsuitability' and 'dissatisfaction')

Mari's interview indicates that, in order to fit in, she learned to "tough it out", suppressing her need for professional support and her wish for professional reflective discussion. Kaarina's account describes frustration about the lack of professional peer reflection, which she experiences as forcing silence upon her: "...either accept things as they are or get out."

The experience of a lack of professional support undoubtedly contributes to teacher attrition. For example, according to the Talis (OECD, 2013), Finnish teachers receive less support in the transition phase than the OECD average, and less in-service training. However, the poststructural lens invites us to look at the experience as part of a discursive context-what does the experience "do" or produce? Both Mari's and Kaarina's accounts suggest a silence arising from the lack of professional support ("no one there has time to talk", "don't ask anyone"). Their accounts highlight similar references to silence in small passing comments in other interviews, such as Mervi's: "It's lonely in the teacher's room. I can understand it, they are all busy and no one has the time to entertain the newcomer;" or "It's tiring, it takes time to learn the rules in each school in which you substitute, what to say and what not to say;", or Annamira's admission: "I hope the next school is open in atmosphere, and I find people to talk with." The question, then, is: if there are silences in which beginning teachers become subjects, what are these silences? What do the silences emerge from, and what

\footnotetext{
${ }^{3}$ All quotes are translated by the author.

${ }^{4}$ All names are pseudonyms.
} 
do they do? What is their significance in the attrition process? I read all the essays and interviews with this thought of "silence," plugging it in to the socio-cultural-historical context.

The above accounts illustrate how new teachers wishing to fit in must learn to respect the "workload" of other teachers in the "hectic field" by not burdening others by asking for peer reflection. Mervi languages her need for professional reflection as "entertaining the newcomer." The "hectic field" and teachers' "workload" are not just easy points of reference for novice teachers who talk about attrition; they also produce discursive boundaries that work to define professional reflection and negotiation, not as an essential part of the work but as "helping" the novice or "entertaining the newcomer" while masking a bigger issue-that there may not be spaces for professional reflection or negotiation, at least for newcomers. The professional need to discuss school practices and the theories, values and intentions behind the practice is silenced, and this is explained in terms of time constraints, making the lack of reflection seem natural and unimportant.

Silences of these kinds are not a consequence of external control but of subjectification and discursive practices. To fit in, novice teachers may learn to perform these silences, as Mari described, or may leave the field, as described by Kaarina. In this way, silences are maintained through discursive practices and through the process of subjectification within such discursive practices. Silences come to be performed by the beginning teachers themselves as they learn the ropes. At the same time, these silences work to set invisible boundaries for professional reflection on the goals and values behind education, and "busyness" prevents the creation of spaces for professional reflection on the values, goals, contexts, and theories of education.

Assessing and criticizing others seems to be at the core of the work, and it does not feel right to me. There is so much focus on stuff like caps being worn inside while bigger and far more important values and issues, like emotional and physical wellbeing, are being ignored. (Tessa, interview, elaborating on 'unsuitability')

\section{(ML: What do you mean?)}

[...] For example, there are the desks, even if they are placed in the U-form, then a break, then the next planned session. There's no room for pupils to think about their own life. Instead, I know from personal experience that they learn how NOT to do it. For example, there's the morning circle where 'everyone can tell,' but you know what to tell and what not to tell. You learn to tell about happy things and invent them if you have none. You don't tell about learning to pay bills or CPR, not about looking for your dad for the entire night because he has passed out in the snow somewhere, you do not tell about the worry or the fear. Then there are the 'My summer trip' essays we wrote. My family never went anywhere, so I wrote about other things. Then the teacher demanded to know why I had failed to do the assignment as instructed. So I learned to be creative, take bits and pieces from my friends' stories, color my life a bit to satisfy the teacher. Then there are the study materials and reading tests. Not all kids have the mental space to study at home, 
and if a string breaks on their instrument, they do not have the money to replace it. (Tessa, recap)

Tessa's essay and interview reveal that she initially chose to become a teacher because she wanted to provide students with a school experience that differed from her own. The above extract from Tessa's recap shows how, in her past life as a pupil in school, she learned to perform silences in respect of the social problems that impacted her life. Now, as a teacher, she cannot find a way out of performing those same silences. Her account describes that silences around social issues come into being because all the spaces for speaking are already occupied by other voices: Everyday school practices uphold implicit structures and norms; to fit in as a teacher, Tessa feels she must still perform the exact silences she hoped to break. Multiple international comparative studies suggest that Tessa's experience is not rare. For example, in PISA 2003, Finnish students reported the weakest sense of belonging at school and the second weakest student-teacher relations among the Nordic countries (e.g. Linnakylä and Malin, 2008). Tessa wants to change this but has learned that she is still impacted by the same implicit structures as when a child, even though she is now a teacher:

\section{I wanted to change all that, but l've only learned how strong the hidden structures are. (Tessa, interview)}

The silences described by the respondents do not center on specific topics (such as racism, as in Mazzei, 2008) but instead work to limit professional reflection itself. The accounts describe how silences work to prevent professional discussion about educational goals and values (e.g., wellbeing versus wearing caps inside). As a result, structures and practices are not agreed through professional negotiation but come to be upheld normatively by discursive practices such as silences. Furthermore, they demonstrate that, although Finnish class teachers are repeatedly and explicitly told that they are professional experts in a decentralized system in which they possess the educational power, they may not necessarily find a space in which to exercise this power. In relation to this finding, all respondents positioned differently. While Mari learned to read and deploy the silences in order to fit in and to perform her way into recognizable and acceptable subjectivity within the school, Kaarina and Tessa described becoming constituted outside the institution, losing their motivation to become teachers in the absence of a space in which to discuss school values and goals.

Don't get me wrong. I am not saying that I do not want to be a teacher. I do. I do. I am saying that in schools, as they are right now, I can't be the teacher I want to be. (Kaarina, interview)

If I sought to become the kind of teacher I want to be, reaching the goals I want to reach, I'd have to be able to change the social structures of a school and my class so that there would be room to be human. (Tessa, interview)

In this way, professional silence not only prevents beginning teachers from engaging with issues they may feel are important but also works to prevent them from becoming the teachers they want to become. This, in turn, is not simply a question of their own professional freedom but relates more 
fundamentally to education: what are the values and goals behind school practices, and is there a discursive space in which to negotiate these?

\section{[...] I want to focus on educating people who can feel whole and accepted, and who feel safe as they are. I do wonder if my values are fundamentally unmatchable with the values in schools. (Elli, interview)}

In conclusion, there are silences in schools that seem natural and inconsequential while implicitly working to prevent professional reflection. In these circumstances, discussing the values and goals of education is not part of school, and the effect is to locate outside of school those educators who wish to renegotiate such values and goals. For beginning teachers in this study, these silences become more than a question of identity and the possibility of becoming the teachers they want to be; more importantly, they raise questions about the goals and effects of school and education itself, and whether they wish to be a part of these.

\subsection{Cultural-historical expectations for teachers}

The "teacher mold"5 that appeared in the essays re-emerged as a theme in the interviews; this is not surprising, as it was explicitly asked about in the instructions. Unlike the first themes which became empty categories, "teacher mold" proved to be an epicenter for many issues, raising a number of questions. If there is a teacher mold that beginning teachers note and discuss as part of their attrition, what is that mold? What is its relevance to attrition? And what does it 'do'? Again, I plugged the discussion of this mold into the surrounding societal discourses.

In formal texts in Finland, there are no officially stated characteristics, criteria or habitus for a good teacher. In contrast, it is part of the popular discourse to say things like "a good teacher can be good in many ways" or "the most important characteristic of a good teacher is wanting to be good and wanting to become better!" ${ }^{6}$ In the Finnish language, there is an old expression, "candle for the people," which is commonly and explicitly criticized by student teachers and teachers at all stages. "I do not think that the contemporary teacher is expected to be any candle" is a common sentence in reflective student essays. This explicit questioning of any normative, traditional cultural-historical representations of teachers is part of the teacher education discourse (Sitomaniemi-San, 2015). A "mold", on the other hand, literally refers to a frame on which something may be constructed. Such a choice of a word creates an image of explicit or implicit normative boundaries for what teachers can become. The word's common appearance in the essays of this research is interesting because it suggests that beginning teachers negotiate with some kind of a normative teacher image, no matter how much such an image is contested in public speech.

During the project reported here, I discussed this topic with student teachers ( $1^{\text {st }}$ to $5^{\text {th }}$ year). The students commonly made statements like "A teacher can look like their self, casual. It's very open and relaxed." At the same time, a student with bright red hair in the program had colored her hair

\footnotetext{
${ }^{5}$ in Finnish, the term 'opettajamuotti' translates directly to "teacher mold". "Opettajamalli," the other term used here, translates to "teacher replica."

${ }^{6}$ http://www.opettaja.fi/cs/opettaja/jutut?juttulD=1408910683879
} 
brown for the entrance interview; a Goth-style student had toned down her makeup significantly for the interview and internships; all but one student covered their tattoos, especially during internships; students discussed at length whether one student teacher should wear pink PVC pants in internships; not one student had ever seen a teacher wearing a Roma dress; and never, in 10 years, have I had a student teacher with brown skin. All of this suggests that while there is a shared illusion that "any teacher is a good teacher," teachers and student teachers actually exercise significant control over themselves and others regarding appropriate habitus and characteristics. However, these cannot be pinned down to anything fixed but are formed in a grid of intersecting discourses (see also Popkewitz, 1998).

There are four things that can be said about such a normative image. First, when asked to define the mold, not one of the respondents provided a definition but only examples of what it maybe is not. This suggests that the normative teacher image appears to beginning teachers as something defined in terms of ambivalent negatives: what maybe not to do, be, or say. Elli and Tessa described "the mold":

You notice the mold only when someone breaks it: joking, yawning, atypical body position, tattoos, piercings, and genre dressing (let's say like a skater), or traditional dressing (such as Roma dresses), or ripped jeans, or women wearing open blouses. And how much can you tell about yourself and your life? Can you say you are gay? It's a violation of human rights if you can't, so officially you can, but by their behavior, others can let you know that it's not ok. (Elli, recap)

I've received so many comments about how un-teacherly I am in my speech, in my way of facing people, and in my habitus in general. I was asked, 'Why do you [wear] earrings that do not match?' I worry I will be constantly inspected by my colleagues. I don't know what a teacher mold is, but I know I am being placed outside of it. (Tessa, interview)

Second, the normative teacher image is produced in social encounters with other individuals in schools - that is, with colleagues. There are no official descriptors, and the normative image is formed completely unofficially and implicitly. These ambivalent normative expectations possibly make the mold even more powerful than, for example, an official list of desirable characteristics or appropriate clothing. When nothing is officially desirable and appropriate, almost anything can be unofficially undesirable and inappropriate. As this normative control seems to take the form of ambivalent negatives, beginning teachers have no way of feeling safe or secure in knowing which vices will place them outside the boundaries of social acceptability as a teacher. Even if they do not agree with a specific norm, they are forced to measure themselves against it. Elli traced her idea of a mold back to the final internship:

The host teacher focused on things like my manner of speaking; for example, she told me not to use -ko/-kö endings with students [which change a verb from an order into a request], emphasized hierarchy, and told me not to talk in too lively a 
Lanas (2017) Giving up the lottery ticket

manner. I don't agree, and I think these are secondary in teaching. Still, as a consequence, I now constantly ask myself, 'Can a teacher do this or talk like this, or does my credibility suffer?' (Elli, recap)

Third, although beginning teachers may not agree with many aspects of the normative image, that image becomes and feels personal to beginning teachers; as the above excerpts show, it marks their habitus, speech, hobbies, sexual orientation, clothing, and emotions. Kaarina described the "teacher mold" as the "role model', the "role model" as the "ideal self," and the "ideal self" as something from which vices are pruned:

The mold of a teacher is a person who is a role model: you must hide a lot, you can't talk unpleasantly; some characteristics must be hidden; anger cannot be shown; everything cannot be said, everything must be known, or the information found swiftly. The teacher mold is the ideal self, and from it, something is always pruned. What is being pruned differs for each teacher-that's why the mold is so difficult to describe. You must put your best side forward. A teacher personality, then, is maybe someone who can do that. (Kaarina, interview)

The teacher-self, as Kaarina describes it, is fluid, adapting to external demands to the extent that the teacher is molded endlessly, and any characteristic is a potential vice that must be pruned. This brings us to the fourth and final point. Although, as described above, beginning teachers are afforded very little professional peer reflection on practices, values, theories and goals in schools, they are expected to reflect extensively on their own appropriateness as teachers. Elsewhere (Lanas \& Kelchtermans, 2015) I have suggested that

students have very little room in negotiating their voluntary and strong investment in shaping their selves. This indicates that the most pervasive norm for beginning student teachers might be precisely the voluntary and strong investment in shaping self. (p. 28)

One specific aspect of normative teacher image that emerged during this research is dedication. Descriptions of personal reflection often revolved around one's own dedication: "I constantly think, is my heart fully in this?" For example, although internships are not formatively assessed-in that the role of supervisors and hosts is supportive rather than officially evaluative, they do not complete evaluative report cards, their feedback is not recorded anywhere, and students know that practically all students need to do to pass is to show up, deliver sufficiently good lessons and write a reflective report-students nevertheless commonly become exhausted during their internship. There is no official external pressure to perform outstandingly, and the workload is a fraction of the regular teacher's workload. (The final internship lasts for 2 months, during which student teachers must teach 30 lessons). However, when describing their attrition, all but two respondents referred to their experiences in the final internship.

I worked from 8 am to $11 \mathrm{pm}$, and I thought about work all the time. (Annamira, interview) 
Lanas (2017) Giving up the lottery ticket

In the two months of the internship, work took me over. I abandoned my hobbies, evening activities, friends; I stopped being myself. My health suffered. It's impossible that l'd be able to work as a teacher only during office hours. Everything I do bears fruit, and the better I do my work, the better the children have it, so how could anything ever be enough? (Riia, interview)

One possible explanation for this exhaustion is psychological, based on personal expectations or personal histories. Again, however, the poststructural lens invites us to ask about the nature of the discourses within which such experiences emerge, and what such experiences "do." While there is an apparent lack of external control, beginning teachers themselves actually take up and exercise control, illuminating the possibility of an education system in which teachers are not controlled externally in any way. The apparent lack of control masks multiple layers of peer- and self-control already learned in pre-service teacher education and internships. When beginning teachers become exhausted or choose to invest no further time, they locate the problem in themselves rather than in the demands placed on them-because officially, there are no demands. They see exhaustion as indicative of their own failure, unsuitability, or lack of requisite characteristics:

I am not unselfish or empathetic enough, and I am not ready for the pressures and responsibilities that being a teacher requires. (Riia, interview)

Maybe I should have thought earlier about my suitability for the field. Now, it's too late. (Pekka, essay)

Rather than assessing external demands, they spoke specifically in terms of "I want," and of demands as their demands of themselves.

I had high demands of myself, and I felt I had to invest everything in it if I wanted to meet those demands. I was stressed, anguished, and eventually exhausted. [...] The lessons went well and I received tons of positive feedback. Still, the stress, anguish, and tiredness did not leave me trusting [in the] image of my future. (Pekka, essay)

I received positive feedback, which fed the pressure to perform even better so that I would keep receiving good feedback. I expected too much from myself; I wanted to do well. The field is free-formed in Finland, and teachers have really free hands to do anything they want; there are no external limitations to how you carry out lessons, so you can always take it further and further. No one else evaluates the teacher officially, but I know if I haven't given my all. If I haven't, I feel I failed the children. (Riia, recap)

The respondents never described failing according to any externally set standards; not once did they mention students' success in tests or negative feedback. They defined their performance not in terms of learning outcomes but in terms of giving all they had, their own commitment, and their own dedication, which were to be endless. 
In conclusion, rather than helping beginning teachers to identify their strengths, be creative, and develop new, imaginative approaches to education, the lack of any official criteria for good teachers in Finland may also lead to normative self-exclusion from school. While there is a normatively controlled image of the appropriate teacher, there is also a language in which this image is explicitly denied. Similarly, while there is very little reflection on the school as a societal context, there is considerable emphasis on the reflecting self. In consequence, when beginning teachers encounter challenges, they may lack any framework in which to assess school as a context in which such challenges occur; instead, they simply locate the problem within themselves, deeming themselves unfit.

\section{Discussion}

Attrition, based on the results of this study, is a complex process of negotiating the transition into the profession. Intersecting discourses come together and may work to cause self-exclusion of beginning teachers who cannot find a subject position within school. The research shows that such negotiations do not take place at surface level. The research was carried out in a context in which teachers are confident that they can perform well in multiple ways, that they have significant autonomy, and that they are dedicated in their work and appreciated in the society; yet new teachers in this study were constantly worried about performing well, found little spaces to use their autonomy, and questioned their dedication. Thus, even in a context in which official structures explicitly encourage reflection on and rethinking of educational practice, goals and value base, and in which there is no official form specifying the qualities of a good teacher, beginning teachers may not find discursive spaces for such professional reflection.

As the discursive boundaries are not maintained by official decision making or discussion, there is also no official space for contesting these discourses. It follows that important discussions about the values and goals of education may not take place openly in the teacher's practical, official, or everyday forums, nor may they be negotiated openly in the professional community. Instead, very important aspects of the profession come to be negotiated as personal questions, as individual teachers decide whether to stay or to leave. Significant educational topics may become excluded from debate as individual teachers take on performatives or constitute themselves outside the teaching force.

Each educational context has historically formed discursive boundaries. Similar discursive boundaries as identified here may be at also in other contexts in which they become concealed by more easily apparent explanations for turnover (accountability, lack of appreciation etc). The discursive boundaries that constitute some beginning teachers outside educational institutions are not simply a personal choice or a structural effect. They are not placed on beginning teachers from above; rather, beginning teachers perform the boundaries as they learn them, subscribe to them, and become their authors by acting them. For those individual beginning teachers who cannot 
subscribe to and author the existing discourses, and cannot therefore find a subject position as teachers, self-exclusion may be a version of assuming power, as they become authors of the discourse by writing themselves a role that lies outside of it.

\section{Conclusion}

I have lost track of many of the participants, while others have sent me occasional e-mails or messages via students to let me know how they are doing. It is notable that some of the participants who were determined they would give up the profession, are now, two years later, working as teachers, while some of the ones who were determined to stay have moved to other things. In this way, the study may not speak so loudly about who stays and who leaves as it speaks about the themes of professional silencing and cultural-historical norms with which all teachers may have to navigate upon entering the profession - and perhaps their need for support during such navigation. Attrition, when seen as a process of negotiating, is not a simple either/or-question, but as a push and pull of exclusive and inclusive discourses within which beginning teachers navigate.

For the participants of this research, the research was a part of their navigation process. There is, however, no means or reason to make claims about the "effect" of the research. For some participants, simply having the space to voice out their concerns may have relieved these concerns.

It was ethically important that throughout our communication that I was supportive of everything they said, took the lead from them and did not push them towards anything. However, as they were talking to me, they were narrating one version of themselves - and they may have later constituted themselves in new ways. I saw one participant much later and as she told me she is now a teacher in another city she said "I said to [another student], Maija would be so surprised to know I ended up a teacher". I wasn't.

I would like to conclude by suggesting one significant implication for pre-service an in-service teacher education. The beginning teachers who leave may have much to give to the field, just no spaces for giving it. This could be alleviated simply by providing such spaces, and by preparing teachers in pre-service education, and supporting them through in-service education to read and discuss critically the surrounding discourses. Developing mentoring and purposeful structures of peer-support could create such spaces. This way, new teachers could avoid locating the problem within themselves and becoming discouraged. Instead of becoming discouraged by the lack of space to engage in discussions, beginning teachers could be taught to create such spaces in school. Such spaces require perseverance, time, sensitivity, and understanding of contextual and historical circumstances. 


\section{References}

Bruinsma, M., \& Jansen, E. (2010). Is the motivation to become a teacher related to pre-service teachers' intentions to remain in the profession? European Journal of Teacher Education, 33(2), 185-200.

Butler, J. (1993). Bodies that matter: On the discursive limits of "sex." London: Routledge.

Butler, J. (1999). Gender trouble. Feminism and the subversion of identity. New York: Routledge.

Clandinin, D. J. (2000). Learning to teach: A question of knowledge. Education Canada, 40(1), 2830.

Clandinin, D. J., Downey, C. A., \& Huber, J. (2009). Attending to changing landscapes: Shaping the interwoven identities of teachers and teacher educators. Asia-Pacific Journal of Teacher Education, 37(2), 141-154. doi: 10.1080/13598660902806316

Cochran-Smith, M. (2004). Stayers, leavers, lovers, and dreamers. Insights about teacher retention. Journal of Teacher Education, 55(5), 387-392.

Coldron, J., \& Smith, R. (1999). Active location in teachers' construction of their professional identities. Journal of Curriculum Studies, 31(6), 711.

Davies, B., Dormer, S., Gannon, S., Laws, C., Rocco, S., Taguchi, H. L., \& McCann, H. (2001). Becoming schoolgirls: The ambivalent project of subjectification. Gender \& Education, 13(2), 167-182. doi: $10.1080 / 09540250120051187$

Green, B., \& Reid, J. (2008). Method(s) in our madness, poststructuralism, pedagogy, and teacher education. In A. M. Phelan \& J. Sumsion (Eds.), Critical readings in teacher education: Provoking absences (pp. 17-31). Rotterdam: Sense Publishers.

Harfitt, G. J. (2015). From attrition to retention: A narrative inquiry of why beginning teachers leave and then rejoin the profession. Asia-Pacific Journal of Teacher Education, 43(1), 22-35. doi: 10.1080/1359866X.2014.932333

Holquist, M. (1990). Dialogism: Bakhtin and his world. London: Routledge.

Jackson, A. \& Mazzei, L. (2012). Thinking with theory in qualitative research: Viewing data across multiple perspectives. Routledge.

Johnson, S., \& Birkeland, S. (2003). Pursuing a "sense of success": New teachers explain their career decisions. American Educational Research Journal, 40(3), 581-617.

Kyriacou, C., \& Kunc, R. (2007). Beginning teachers' expectations of teaching. Teaching and Teacher Education, 23, 1246-1257.

Lanas, M., \& Kelchtermans, G. (2015). "This is more about me than my skills" - Student teacher subjectification in Finnish teacher education. Teaching and Teacher Education, 47, 22-29.

Linnakylä, P. \& Malin, A. 2008. Finnish students' school engagement profiles in the light of PISA 2003. Scandinavian Journal of Educational Research 52 (6), 583-602.

Macdonald, D. (1999). Teacher attrition: A review of the literature. Teaching and Teacher Education, 15, 835-848.

Malderez, A., Hobson, A. J., Tracey, L., \& Kerr, K. (2007). Becoming a student teacher: Core features of the experience. European Journal of Teacher Education, 30(3), 225-248. doi: 10.1080/02619760701486068

Malinen, O.-P., Väisänen, P., \& Savolainen, H. (2012). Teacher education in Finland: A review of a national effort for preparing teachers for the future. The Curriculum Journal, 23(4), 567-584.

Mazzei, L. (2008). Silence speaks: Whiteness revealed in the absence of voice. Teaching and Teacher Education, 24(5), 1125-1136.

Moir, E. (1999). The stages of a teacher's first year. In M. Scherer (Ed.), A better beginning: Supporting and mentoring new teachers (pp. 19-23). Alexandria, VA: Association for Supervision and Curriculum Development. 
Nissinen, K., \& Välijärvi, J. (2011). Opettaja- ja opettajankoulutustarpeiden ennakoinnin tuloksia. [Results of anticipating teacher needs and teacher education needs]. Jyväskylä: Jyväskylän yliopistopaino.

OECD (2013). Teachers' salaries. In Education: Key Tables from OECD, No. 1. doi: 10.1787/teachsal-table-2013-1-en

OECD. (2013) Talis. Retrieved from http://stats.oecd.org/Index.aspx?datasetcode=talis 2013

OECD. (2014). Talis. Education at a glance 2014, Finland. Retrieved from http://www.oecd.org/edu/Finland-EAG2014-Country-Note.pdf

Ostinelli, G. (2009). Teacher education in Italy, Germany, England, Sweden and Finland. European Journal of Education, 44(2), Part II.

Phelan, A., Sawa, R., Barlow, C., Hurlock, D., Irvine, K., Rogers, G., \& Myrick, F. (2006). Violence and subjectivity in teacher education. Asia-Pacific Journal of Teacher Education, 34(2), 161-179. doi: 10.1080/13598660600720561

Pillen, M., Beijaard, D., \& den Brok, P. (2013). Professional identity tensions of beginning teachers. Teachers and Teaching: Theory and Practice, 19(6), 660-678. doi: 10.1080/13540602.2013.827455

Popkewitz, T.S. (1998). Struggling for the Soul: The Politics of Schooling and the Construction of the Teacher. New York and London: Teachers College.

Rots, I., Kelchtermans, G., \& Aelterman, A. (2012). Learning (not) to become a teacher: A qualitative analysis of the job entrance issue. Teaching and Teacher Education, 28, 1-10.

Schaefer, L. (2013). Beginning teacher attrition: A question of identity making and identity shifting. Teachers and Teaching: Theory and Practice, 19(3), 260-274. doi: 10.1080/13540602.2012.754159

Simola, H. (2007). The Finnish miracle of PISA: Historical and sociological remarks on teaching and teacher education. Comparative Education, 41(4), 455-470.

Sitomaniemi-San, J. (2015). Fabricating the teacher as researcher: A genealogy of academic teacher education in Finland. University of Oulu. PhD thesis. Acta Universitatis Ouluensis.

Skaalvik, E., \& Skaalvik, S. (2011). Teacher job satisfaction and motivation to leave the teaching profession: Relations with school context, feeling of belonging, and emotional exhaustion. Teaching and Teacher Education, 27, 1029-1038.

Smith, T. M., \& Ingersoll, R. M. (2004). What are the effects of induction and mentoring on beginning teacher turnover? American Educational Research Journal, 41(3), 681-714. doi: 10.3102/00028312041003681

St. Pierre, E. A. (2013). The Appearance of Data. Cultural Studies/Critical Methodologies, 13(4), 223227. doi: $10.1177 / 1532708613487862$

Struyven, K., \& Vanthournout, G. (2014). Teachers' exit decisions: An investigation into the reasons why newly qualified teachers fail to enter the teaching profession or why those who do enter do not continue teaching. Teaching and Teacher Education, 43, 37-45.

Sumara, D., Davis, B., \& Iftody, T. (2008). 101 ways to say "normal." In A. M. Phelan \& J. Sumsion (Eds.), Critical readings in teacher education: Provoking absences (pp. 155-172). Rotterdam: Sense Publishers.

Taguchi, H. L. (2005). Getting personal: How early childhood teacher education troubles students' and teacher educators' identities regarding subjectivity and feminism. Contemporary Issues in Early Childhood, 6(3), 244-255.

Thomson, M., Turner, J., \& Nietfiel, J. (2012). A typological approach to investigate the teaching career decision: Motivations and beliefs about teaching of prospective teacher candidates. Teaching and Teacher Education, 28, 324-335. 
Wang, H., Hall, N., \& Rahimi, S. (2015). Self-efficacy and causal attributions in teachers: Effects on burnout, job satisfaction, illness, and quitting intentions. Teaching and Teacher Education, 47, 120-130.

Webb, R., Vulliamy, G., Hämäläinen, S., Sarja, A., Kimonen, E., \& Nevalainen, R. (2004). Pressures, rewards and teacher retention: A comparative study of primary teaching in England and Finland. Scandinavian Journal of Educational Research, 48(2), 169-188.

Youdell, D. (2006). Diversity, inequality, and a post-structural politics for education. Discourse: Studies in the Cultural Politics of Education, 27(1), 33-42. doi: 10.1080/01596300500510252

Zembylas, M. (2003). Emotions and teacher identity: A poststructural perspective. Teachers and Teaching, 9(3), 213-238.

Zembylas, M. (2005). Discursive practices, genealogies, and emotional rules: A poststructuralist view on emotion and identity in teaching. Teaching and Teacher Education, 21(8), 935-948.

Zembylas, M. (2007). Theory and methodology in researching emotions in education. International Journal of Research \& Methods in Education, 30(1), 57-72. 